\title{
A Land Value Capture Property Tax Schedule for Municipal Infrastructure Financing in Lagos State, Nigeria
}

\author{
Funlola Famuyiwa ${ }^{1}$
}

${ }^{1}$ Department of Estate Management, University of Lagos, Nigeria.

To cite this article: Famuyiwa, F. (2020). A Land Value Capture Property Tax Schedule for Municipal Infrastructure Financing in Lagos State, Nigeria. Journal of African Real Estate Research, 5(2), pp.75-105. DOI: 10.15641/jarer.v5i2.877.

\begin{abstract}
This study develops a land value capture property tax rates schedule for use in Lagos state, Nigeria, in order to aid sustainability in municipal infrastructure financing. With the poor state of infrastructure in Lagos, the LVC property tax is advanced as a sustainable means of infrastructure reform through equitable rates. Using a sample from Alimosho - the largest local government area in Lagos - a hedonic regression model is used to determine the financial contributions of municipal infrastructure in property values to show their varying influences. From the regression analysis, the schedule is then derived, which is broadly premised on a quid pro quo basis. This stems from the fair notion that the pecuniary influences of municipal infrastructure should be recovered in the form of property taxes for public gains. Not previously done in the region, the schedule determines rates payable on property taxes and are reflective of the monetary influences that municipal infrastructure confer on property values. The proposed rates schedule also take into account varying distances of locational infrastructure and their impacts on property values. The use of Geographic Positioning System (GPS) in the study represents an advancement of previous Nigerian studies on infrastructure and property values where fewer infrastructure types have been considered or less precise measurement indices have been used. The study concludes that this LVC property tax approach will engender a sustainable, equitable, and efficient source of local financing for infrastructure delivery and operations. This is because it builds a veritable rates base and it enables ratepayers to face the actual costs of benefits received from infrastructure services.
\end{abstract}

Keywords: Land Value Capture; Property Taxes; Hedonic Pricing; Infrastructure Finance; Lagos State

\footnotetext{
${ }^{1}$ funlolafam@yahoo.com
} 


\section{Introduction}

Whilst increased urbanisation provides economic opportunities such as jobs and increased livelihoods, it also comes with planning and development challenges such as traffic congestion and poor access to public facilities. The rapid and uncontrolled population growth characteristic of cities in developing countries triggers a growing need for infrastructure, such as road developments, public amenities and transportation services. In Lagos state, Nigeria the rising infrastructure demand occasioned by the astronomical growth in population, has resulted in very visible infrastructure investment deficits (Soyeju, 2013). Governments at various tiers are in a constant battle to resolve this infrastructure challenge. Because public sector sources alone are inadequate to close the deficits, scholars such as Babawale (2013) and Famuyiwa (2019) prescribe and provide deeper insight into the innovative use of property taxes in supporting urban infrastructure and development.

The Property tax is a periodic levy on real estate, usually based on property values, just as income tax is based on income. According to Abbott (2008), it is levied against the deemed value or income arising from property. This tax is traditionally imposed by local governments, for expenditure on municipal infrastructure such as fire services, street lighting, waste disposal and cleaning services. Collier et al. (2018) thus explain that property taxes are seen as the price paid for public investment in services and infrastructure. Real estate is taxed because it represents most of the demand for municipal infrastructure. According to Bahl (2009), people shop for a community that provides the services they demand, and then pay for these services with the property tax. Walters, Sietchiping, and Haile (2011) similarly submit that if there were no real estate developments, there would be little need for the services that must be funded through taxes, as property users, carrying out activities that use sanitation, roads etc., create the demand for these public services. Essentially, the property tax is rooted largely in the 'benefits principle' of taxation and functions as a 'user-charge' on local residents for the benefits they receive (Institute of Taxation and Economic Policy, 2011). Tax rates in most jurisdictions, however, do not reflect this nexus. Ahmad, Brosio and Pöschl (2014) aver that there is little linkage of the property tax with service delivery. In Lagos state, Nigeria for example, policy only shows the rates derivation formula; and bills show tax liabilities. Suzuki et al. (2015) point out that taxpayers thus often contest the coverage and amount of taxes or fees because the definition of benefits created by public intervention is often vague. Further, the accuracy of the estimated incremental value is often challenged, and the calculation methods are not well defined. This causes low resource mobilisation (Babawale \& Nubi, 2011), where appreciable returns are not yielded when compared to potentials. McGaffin et al. (2016) point out that the viability and success of this income generating mechanism, depends to a large degree on the ability to directly link the tax to the benefits received. This is of particular relevance in Nigeria where there is no evidence found that the revenue raised from the Lagos state Land use Charge was used to finance infrastructure (UKAid, 2015). 
Economic theory provides the means to measure the influence of municipal infrastructure benefits in property values - as can be traced to the works of Rosen (1974). As such, a more equitable approach of rates determination which creates a definitive link between taxes paid and benefits received from municipal infrastructures can be achieved. This has the potential to increase accountability of government officials whilst making the tax more endearing to ratepayers. Parsons and Noially (2004) describe this as 'Land Value Capture' (LVC) taxing which can be applied in any case where a public facility leads to increases in nearby property values. Generally, infrastructure have distinct and significant values to building users, and their proximate availability have substantive impacts on real estate pricing and value (Johnson-Gardner, 2007). This emanates from functionality, service advantages, utility and convenience expressed in savings in time and costs (Famuyiwa \& Babawale, 2014). LVC taxing is essentially a land-based financing (LBF) strategy which recovers in taxes, some or all of the gains in property values, realised from nearby public investments like infrastructure for reinvestments or debt servicing. In Germán and Bernstein's (2018) study, property taxes were shown to be an important form of LVC, because wellfunctioning property tax systems base obligations on the market value of real estate. Property taxes that capture the rising value of real estate, have been hailed by economists as fairer and more efficient than other taxes (Haas, 2017). The concept of 'land value capture' has thus become a standard argument for implementing or reforming taxes based on real estate (Walters, 2013). When implemented well, it is highly transparent, citizens can clearly see how taxes are spent, and are able to hold local governments accountable (Smolka, 2019). As challenges mount from rapid urbanisation, deteriorating infrastructure, and more, the LVC as a funding source has never been more important to the future of municipalities (German \& Bernstein, 2018).

The concept of LVC has been demonstrated in a number of ways in existing literature with the use of the 'hedonic regression pricing', by several scholars such as Parsons and Noially (2004); Medda and Modelewska (2010); and Suzuki, Murakami, Hong and Tamayose (2015). Using hedonic regression, this study aims to demonstrate how the LVC property tax can be applied in Lagos state, Nigeria using Alimosho local government area. The second section of this paper discusses narratives on the LVC in terms of previous studies on it, its use potentials and guidance on an equitable rates schedule in Lagos, Nigeria. The hedonic regression pricing, which reveals the influence of available infrastructure on residential property values is used as a basis towards deriving an equitable LVC rates schedule in the third section. In the fourth section of the paper, a schedule is derived. The schedule is broadly built on the notion that the pecuniary contributions of infrastructure should be captured back in the form of property taxes, which in turn will financially sustain municipal infrastructure investments. This is based on fairness. This schedule determines rates payable on properties and are reflective of the monetary influence that municipal infrastructure confer on property values. Conclusions and recommendations arising from the study can be found in the fifth section. 


\section{Land Value Capture and Municipal Infrastructure}

"The tax upon land values is the most just and equal of all taxes. It falls only upon those who receive from society a peculiar and valuable benefit, and upon them in proportion to the benefit they receive. It is the taking by the community, for the use of the community, of that value which is the creation of the community."

(Henry George, 1879)

McGaffin et al. (2016) describe LVC as the process of extracting the additional value that accrues to a property following different types of public investments. Common LVC tools include public land leasing, linkage or impact fees, business improvement districts, and certain applications of property tax (Lincoln Institute of Land Policy, 2019). Figure 1 (adapted from Siba \& Sow, 2017) shows the LVC process, which generates a cycle in which value is created, realised, and invested/re-invested in municipal infrastructure. The cycle shows that infrastructure investments are made with institutional support, enabling policies, efficient local government correspondence, administration etc. Taxes are then extracted on the basis of value contributions (implicit prices) of municipal infrastructure in property values. These value contributions also provide indicators of demand for various types of infrastructure. This is because hedonic regression pricing models are depicted in the demonstration of effective demand as opposed to projected perceptions of demand (Famuyiwa \& Babawale, 2014). Ultimately, these realised gains are then invested or re-invested into infrastructure projects, and or used for debt servicing.

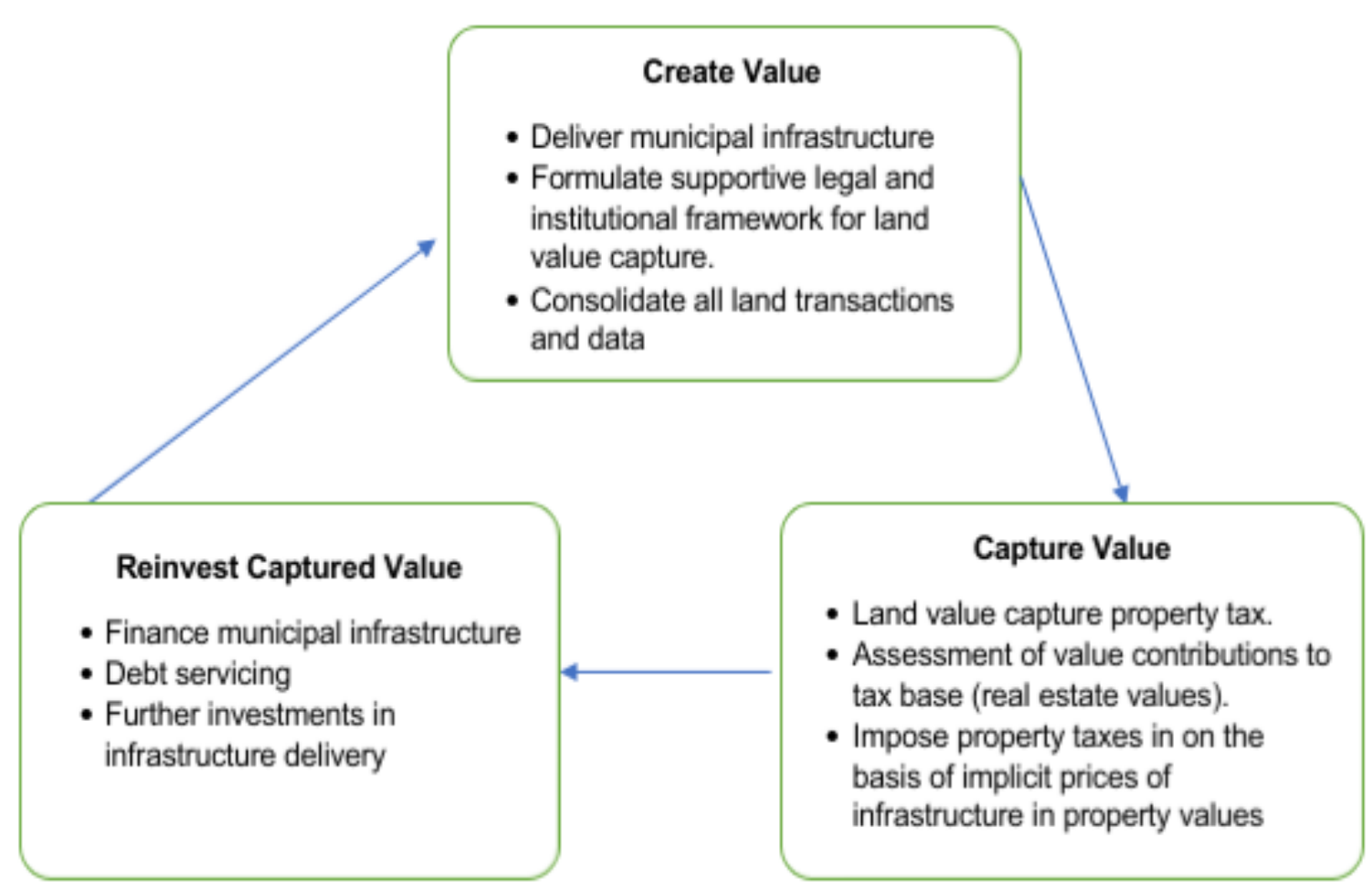

Figure 1: The Land Value Capture Process

(Adapted from Siba \& Sow, 2017) 


\subsection{The benefits of a land value capture tax}

As to why property tax rates should be linked with benefits received from municipal infrastructure, a few justifications particularly for Lagos state, Nigeria as collated by Famuyiwa (2019) and adapted here, are seen below.

\section{i) Credibility in government and compliance with the tax system}

LVC taxes are built on the notion that pecuniary contributions of public investments in real estate values, should be commensurately captured back in form of property taxes, creating a fair exchange between rates paid and service benefits received. In this way, policy makers are made more accountable. Prichard (2017) explains that where taxpayers do not believe that tax revenues correspond with public service provision, they are less likely to comply with taxes, and may hold more broadly negative views of government. Further, effective connections between revenue and services enhances trust in government, contributing to tax compliance and broader government credibility. Similarly, Smolka (2019) points out that with the LVC, citizens are able to hold local governments accountable as it is highly transparent. The UN-Habitat (2020) similarly states that if the connection between taxes paid and infrastructure and services is obscure, tax compliance will suffer.

\section{ii) Revenue enhancement and infrastructure development}

When taxes are seen as equitable, and representing a fair exchange for public services, revenues are positively impacted. 'Compliance' (mentioned above) aids revenue collection. Nzioki and Osebe (2014) note that compliance levels influence revenue generation in property taxation. With the LVC aiding compliance, revenues are boosted and so is spending on infrastructure and development. Pritchard (2017) notes that connection between revenue and spending are linked. This is because the connection will generate popular support for promised spending, leading to the creation of specific structures for delivering on that spending.

\section{iii) Eliminating the 'freerider' problem}

In addition to the highlighted points above, the LVC helps eliminate the 'freerider' problem. The 'free-rider' problem arises where the usage of certain types of infrastructure is not controlled or regulated because there is no market or price mechanism to regulate their use. Simply put, such infrastructure types, have no price tags attached to them. Municipal infrastructure, such as streetlights or sidewalks (non-exclusionary and nonrivalrous goods) fall into this category, where usage is uncontrolled, 'unexcludable', and available to all at no specific cost to users (Otegbulu, 2010). Such services are therefore best funded through the LVC. This is because the LVC creates implicit prices and thus helps deal with the effects of such pricing failures.

As seen in the benefits of the LVC tax presented above and considering the pressing need for infrastructure reform in Lagos, this study helps set the stage for infrastructure reform in Lagos, through a sustainable means by developing 
an equitable tax rates schedule. The benefits listed above contribute to the justification of this means (i.e. LVC) to help close the municipal infrastructure deficit in Lagos state, sustainably. The rates schedule proposed will will help address fiscal challenges of budget and inequitable rates. Huston and Lahbash (2018) submit that the arguments for LVC expansion on economic, strategic, fiscal and equity grounds are impelling.

\subsection{Financing sustainability of municipal infrastructure in Lagos: The land value capture in perspective}

Sub-Saharan African (SSA) cities are generally burdened by high urban infrastructure deficits and associated limitations to accessing services (UKAid, 2015). In Nigeria, municipal infrastructure development has been unsustainable. Soyeju (2013) writes that analysing the state of infrastructure in Nigeria presents a spectacle of the crushing lack of infrastructure assets across the nation. Unfortunately, infrastructure investments are characteristically capital intensive. According to Famuyiwa (2019) the delivery of infrastructure clearly requires significant investment in financing as well as related funding on operation, maintenance, and where applicable, debt servicing. In modern times, government spending alone in this regard is fast becoming inadequate. Ikpefan, Ailemen and Akande (2010) assert that public sector resources alone will be grossly inadequate to finance the necessary infrastructural development needed to drive the economy. PublicPrivate Partnership (PPP) arrangements, or other debt financing mechanisms are sustainable possibilities (Famuyiwa, 2019). Private sector participation is now well-recognised to help bridge the deficit, while complementing government efforts (Adeyemi et al., 2015). However, in such instances, there must be viable plans for repayment of loans sourced from the private sector. Such viable plans identified in literature include well-structured property tax systems (Walters, 2013; Suzuki et al., 2015). Similarly, Istrate and Puentes (2011) point out that any PPP project, requires a revenue source for repayment such as tolls, or fees from land value capture. Babawale (2013) elucidates that agencies (in particular the World Bank) have at various times under the aegis of the Infrastructure Development Fund (IDF) prescribed efficient property taxation as prerequisites for financial support for urban infrastructure and development. Walters (2013) reports that the LVC concept has become a standard argument for reforming property taxes, as substituting land-based taxes for other taxes to pay for infrastructure investments is economically efficient. Chapman (2016) similarly identifies LVC as a significant means of solving infrastructure funding problems.

In Lagos, Nigeria, the LVC holds a lot of potential for use. Firstly, is the prospect associated with the rapidly growing and large population of the city. Haas (2019) explains that the LVC is a powerful instrument for rapidly growing cities. Oualalou (2012) writes that by producing immediate substantial revenues, which reduces dependence on debt, the use of LVC is well adapted to cities witnessing particularly fast urban growth. Essentially, the population growth and the public investments leading to increased land values should not accrue to private investors - but channelled back to the public. Secondly, is the benefit inherent in utilising land to generate wealth 
which the LVC is characterised by. Experts such as Tomori (2003) have explained that the wealth in Nigeria from land is more than enough to develop and sustain local governments, states, and the Federal Capital Territory (FCT) if it is well managed and administered.

\subsubsection{Institutional and legal prerequisites in implementing Land Value Capture in Sub-Saharan Africa}

In spite of this ever-growing consensus on LVC regarding the opportunities on issues such as infrastructure funding gaps, equity, sustainability, regional growth and development, there are constraints it faces in use and implementation. These constraints primarily relate to institutional and policy demands of LVC. Huston and Lahbash (2018) note that despite the widespread conviction that a proportion of 'unearned increments' should somehow be harvested for the wider public good, pragmatic and legal challenges remain. These pragmatic challenges are concerned with institutional' expediencies. Studies point to the role and capacity of local governments in this regard (Walters, 2013; UKAid; 2015). The UKAid (2015 p. iv) asserts that the directives from national institutions and particularly the capacity of local governments for the management of infrastructure - being a public good - is key to success. Local governments should hold authority over service management of municipal infrastructure, otherwise there will be inefficiencies and 'skewing of access to infrastructure'. Also is that poorer households would be neglected in favour of servicing non-residential and higher income residential property owners. Walters (2013) similarly advocates for decentralised authorities to implement LVC systems. In addition, because LVC systems include legal and spatial designation of schemes for ease of administration, Famuyiwa (2020) points out that local governments being in closest proximity to municipalities, must be included in administration. Unfortunately, in SSA, the role and influence of local governments, 'tipped over' by national governments in the region, act to constrain the opportunity for LVC (UKAid, 2015). In Lagos, Agwu (2019) explains that the federal government's tacit withdrawal of autonomy has become the bane of local government administration in Nigeria leaving local governments overwhelmed and incapacitated. Adegbenjo (2003), for example, states that there is very little known by local governments in terms of property inventory and information, making it virtually impossible to exercise proper authority over the land under their administration. Thus, institutional expediencies must take place in the areas of an effective and controlled framework for revenue collection, land geographic information systems, urban planning and tenure $\&$ registration systems. (Committee on Local Finance for Development, 2014). Furthermore, institutional challenges must be tackled by establishing local government fiscal autonomy. LVC systems can help support this.

Where legal issues are concerned, there should be clear policy intent on local government autonomy in both the raising of LVC taxes, and the managing of LVC arrangements. The UKAid (2015) submits that that it is essential to have a policy in LVC to provide a framework on issues like the functions of various players in the system such as administrators, and the state. Further, the policy 
should provide for the financing method from the private partner and repayment approach. Essentially, such laws spell out the obligations of infrastructure service providers, and the financing arrangements for repayment. In Lagos, there are no laws specifically targeted at LVC financing mechanisms - to the author's best knowledge. In Famuyiwa (2020) land value capture is not expressly provided for in existing municipal legislations for infrastructure delivery. This presents various uncertainties with respect to legal questions around billing systems, debt collection, the designation of the LVC districts and requirements for public participation. Also, is relating this within the existing property tax law. The closest policy to LVC in terms of providing a framework for infrastructure financing arrangements is the Lagos state 'Public Private Partnership (PPP) Law of 2011' which, as the name implies, is a PPP policy ${ }^{2}$. In Lagos, key features of the PPP law centre around the establishment of the office of Public Private Partnership, procurement of private sector partners for infrastructure development, amongst others. However, the law is not strategic in terms of utilizing the land value uplifts attributable to infrastructure developments. According to Soyeju (2013), legal frameworks should necessarily include industry specifics (such as technical inputs needed). Also, the terms and the templates through which financial capital will move, must be defined. This remains a challenge for the use of LVC in Lagos state. Thus, the lack of clear and strategic policies on infrastructure finance act to constrain LVC. (UKAid, 2015).

PPP policy can however be enhanced to include the determination of value increases in property from infrastructure investments, as well as the inclusion of key elements necessary for effectively implementing LVC. The Ministry of Urban Development (2017) notes that the LVC encourages and facilitates the intervention of PPPs, resulting in a legal basis for introducing financial benefits from investment due to increased land values. In attaining robust policy formulation or reforms, the UKAid (2015) submits that in advocating for LVC with national governments, international development agencies can provide support in preparing policies - through the Department for International Development (DfID). Despite the legal and institutional challenges that need to be navigated in order for the effective implementation of LVC, it is argued that the benefits in terms of providing a more equitable and efficient tax system to better fund infrastructure, outweigh the challenges.

\subsection{The use of land value capture in Sub-Saharan Africa}

In SSA countries like Nigeria, its use is relatively limited- as are discussions on the topic. Bahl et al. (2018) explain that the use of LVC to finance infrastructure has been commonly used in developed economies, for example for Hong-Kong's mass transit railway network, as reported by Verougstraete and Zeng (2014). Similarly, McGaffin, Viruly and Boyle (2019) note that research on the use of LBF in financing infrastructure has tended to focus on

\footnotetext{
${ }^{2}$ Essentially, PPPs are financial contractual agreements between a public entity and a private sector party, for providing infrastructure for the public, through greater financial participation and risk burden placed on the private party. Any PPP project requires a revenue source for funding repayments which may take the form of tolls, local or federal funding, or fees from land value capture (Istrate \& Puentes, 2011)
} 
Europe, the USA, South America and Asia. In the SSA region, some narratives also provide insight on LVC and advocate for their use. These narratives- such as Brown-Luthango (2010); McGaffin, Viruly and Boyle (2019) - however, stem from South Africa. In Nigeria the LVC remains loosely featured in literature as seen below (limited to Famuyiwa, 2017; Ibrahim \& Fosudo, 2017).

Brown-Luthango (2010) reviewed case studies on the use of taxing land value increments from infrastructure provision, and how the concept holds possibilities for South Africa. It was found that more research was needed to model the effect of public infrastructure on land values. In addition, the study found that the instruments suitable in the South African context, such as betterment taxes, needed to be further explored. Finally, the study recommended a supportive legislative framework with clarity of purpose. Similarly, McGaffin et al. (2016), highlighted how value-capture could address the infrastructure challenges in South Africa. The study concluded that legislations should be reviewed, streamlined and have clarity- especially on issues relating to value assessments, and district delineation. Lombard, Behrens and Viruly (2017) conducted a case study to evaluate the effect of a newly constructed rail infrastructure project (Gautrain rail network) on adjacent residential property values. The study concluded that given a direct correlation between increased property values and infrastructure additions in some contexts in the study area, there was potential for the use of value capture. McGaffin, Napier and Gavera (2014), looked at two elements of the LVC process, namely the 'capturing of value', and 'the use of funds resulting from the captured value'. The focus was on the legal framework for use in the South African context. The conclusion was that legislation was vague and inconsistent. Further, it was asserted that the LVC would be most successful with clear policy objectives. McGraffin, Viruly and Boyle (2019) looked into issues surrounding how land-based financing (LBF) mechanisms could be used to overcome public infrastructure funding constraints in South Africa. Using a literature review the study found that other land financing mechanisms, such as tax-increment financing (TIF), that were currently not used would be better suited due to the reason of borrowing capacity of municipalities in South Africa. Suzuki et al. (2015) observed that majority of cities in developing countries had not yet fully explored the benefits of LVC, due to lack of a consistent vision, strategy, policy and institutional framework. The study also found that LVC exposed limitations relating to technical expertise, capacity, and experience. Other studies emanating from Africa, such as Biitir (2009), found that in Ghana the lack of enforcement of land use regulations, and knowledge gaps among key stakeholders was a major issue with the use of LVC. Ibrahim and Fosudo (2017) encouraged the use of LVC in infrastructure delivery for cities like Lagos state, Nigeria. They further highlighted the challenges of its implementation in Nigeria were insecure land ownership arrangements and insufficient property market data. Famuyiwa (2017) advocated for the use of value capture instruments and LBF strategies for infrastructure finance in Nigeria. A major observation of the study was the policy gap in Lagos. 
The LVC studies reviewed above however, focus on issues of policy, administration, market systems, workability, operational issues and or modern high-tech mass transit systems. Little or no research has been done on the taxation of windfall gains from public infrastructure for LVC application in Nigeria. Particularly, the foci of these studies were not on developing LVC tax rates schedules. Thus, these gaps in literature reveal the need for this present study. Also shown, is the need for more studies in Nigeria.

\subsection{Land value capture property tax rates}

Where rates based on benefits received from infrastructure services are concerned, Slack (2006) writes that authorities may levy rates, according to services received on the basis of fairness. Essentially, rates should be commensurate with benefits received. This is because benefits derived from local public services are capitalised differently into property values. Evidence from literature generally shows little guidance on the use of circumstantial approaches in the setting of tax rates. According to Berniaz (2009), there are very limited studies on the subject of property tax rates. While Kennedy and McAllister (2005) hold a similar view that research on the principles of property tax rate setting continues to be negligible, it is noted that setting tax rates, the principles that formed the foundation of a tax policy (such as LVC) must be considered. This means that the guiding philosophy upon which the tax system is premised, such as fairness in terms of 'benefits received', should be reflected in rates. As advanced by Parsons and Noially (2004), LVC tax rates cover budgetary requirements and are also proportionate to benefits derived from municipal infrastructure. The LVC property tax rate should thus take into consideration the budgetary requirements (revenue expected by the public authorities from the property tax revenues) and benefits received from the tax. Baker and Dyson (2008) similarly state that the rates schedule used, must correspond to a market analysis for the specific characteristics of the property. McGaffin, Napier and Gavera (2014) explain that one key element in value capture taxation is the 'capturing of value' which corresponds to establishing a tax schedule or tax rate. This 'represents' the very essence of this study.

In addition to these highlighted considerations, the researcher recommends the consideration of a 'rateable' or 'taxable' value, as the value capture proposition in this study is not a one-time tax, rather, a recurring one where ratepayers in residential properties, as well as other property classes, are faced with this burden periodically (usually annually). The rateable value is derived when a percentage (e.g. 60\%) is applied to the rental (property) value before the tax rate is then applied. It is a percentage of rental value, upon which the percentage of benefits from municipal infrastructure is then applied. In Lagos, the 'rateable value' corresponds to a 'general relief rate' well espoused by lawmakers, in section 10 of the long-standing property tax law (The Land Use Charge Law-LUCL). This 'general relief rate' reduces tax liabilities, thereby generating lower tax bills and reducing liabilities on ratepayers. In Lagos state, bills are reduced by $40 \%$ by this general relief rate. Melnick et al. (2009) point out that relief essentially attempts to produce a smaller tax bill for at 
least some taxpayers. The altruism currently upheld in the LUCL will therefore be preserved in this proposed land value capture property tax. The UNHabitat (2020) states that revenue policies in land-based financing systems should be consistent with local values. Further, tax reliefs are usually granted to induce economic development and are thus appealing to taxpayers. The general relief rate essentially makes the tax more endearing, amenable to ratepayers thereby encouraging compliance.

The three considerations outlined above, namely: (a) budgetary requirements of the municipality or local authorities; (b) financial influence (implicit prices) of municipal infrastructure in property values; and (c) rateable value of properties; are to be considered in setting a tax schedule. The idea is to replicate these guiding considerations on LVC property tax rates in the study area.

The discussions above have provided insight on situating the LVC in Lagos state. The benefits, the operational challenges and the policy issues are highlighted in this section. The issue of a rates schedule- being a major gap in previous studies in addition to little or no guidance on its derivation- is also discussed in this chapter. The use of the LVC has at best, been demonstrated in a number of ways in existing literature with the use of the 'hedonic regression pricing'. Upon the hedonic regression pricing, which creates a definitive link between infrastructure and property values, a rates schedule can then be derived.

\section{Research Methods}

This study addresses two research questions. Firstly, what are the pricing effects-if any- of various municipal infrastructure on property values in the study area? The second research question seeks to understand how these pricing effects can be captured as a basis for property taxation. The following sub-sections explain in detail how the first research question is answered. The second research question is tackled in section 4 .

\subsection{Hedonic Regression Technique}

The provision of infrastructural facilities has been established to have a direct relevance to the changes that may occur in residential property values (Ajayi et al., 2015). This has been demonstrated with the use of hedonic pricing in several studies such as Weinberger (2001); Larsen and Blair (2010); and Liman et al. (2015). Furthermore, several studies such as Medda and Modelewska (2011), Wang, Potoglou, Orford, and Gong (2015), Neville (2016), McIntosh,Trubka, Newman and Kenworthy (2017), used hedonic pricing to demonstrate the pricing effects of public amenities in property values for equitable tax schedules. Babawale and Johnson (2012), submit that the basic premise of the hedonic function is that a property represents a bundle of attributes which all contribute to its value. Tse and Love (2000) explain these property attributes to broadly include structural, neighbourhood and locational attributes (these attributes are discussed in sub-section 3.1.1 below). Babawale and Johnson (2012) further explain that the price of 
property is the sum of the implicit prices (value contributions) for each of its attributes. A specific functional form (relationship) is therefore assumed to exist between these attributes and the value of the property. The functional form (hedonic price function) simply refers to the algebraic expression stating the relationship between the dependent variable (in this case property rental values) and the independent variables (property attributes). Malpezzi (2002) explains that the hedonic pricing analysis is a functional relationship between the price of a property and its characteristics in algebraic form. Functional forms quite often considered, include the 'linear', 'log-log' and 'log-linear' expressions (Babawale \& Johnson, 2012). With the 'log-log', both dependent and independent variables are expressed in logarithmic forms. With the linear form, the exponential power of the dependent and independent variables is ' 1 '. The log-linear's dependent variable is expressed in a logarithmic form, while the independent variables are not. It is vital to choose the right functional form. Dunse and Jones (1998) write that the choice of the functional form used will influence the results generated. From previous studies such as Babawale and Johnson (2012); Famuyiwa and Babawale, 2014; and Famuyiwa, 2019; a log-linear form (as shown below) is best considered. Further, Selim (2009) advocates for the use of the log-linear form in hedonic studies because it fits the data particularly well and its coefficient estimates can be interpreted as being the proportion of a good's price that is directly attributable to the respective characteristics of that good.

Hedonic analysis is used in this study to determine the impact of municipal investments/facilities on property values. Thus, the independent values are those that impact the property value (in this case rental value). The independent variables broadly consist of structural, neighourhood and locational attributes, as the functional form above depicts. Of key interest in this study, are 'locational' and 'neighbourhood' characteristics jointly referred to as 'municipal infrastructure' which will be featured in the LVC rates schedule. As mentioned in section 2.5 , the rates schedule will include the financial influence (implicit prices) of municipal infrastructure in property values (among others). Famuyiwa (2019) describes municipal infrastructure as those publicly provided facilities serving local neighbourhoods and are designed to aid and ease of domestic, economic, and other productive activities within the are they cover. Examples include streetlights, fire services and pedestrian walkways. Here, municipal infrastructure represents both neighbourhood municipal infrastructure ("neighbourhhod characteristics' in the hedonic functional form) and locational municipal infrastructure (locational attributes in the hedonic functional form)- as seen in the equation (1) below.

$$
\mathbf{P}_{\mathbf{n}}=\beta_{0}+\beta_{\mathrm{s}} \mathrm{S}_{\mathrm{ij}}+\beta_{\mathrm{l}} \mathrm{L}_{\mathrm{ij}}+\beta_{\mathrm{n}} \mathrm{N}_{\mathrm{ij}}+\mathrm{Z}_{\mathrm{ij}}
$$

Where: $P_{n}=$ Annual rental value of property (dependent variable).

$\beta_{0=}$ The constant (The 'Constant' or the ' $Y$-intercept'. It represents the average value of the dependent variable in the absence of all predictors. It's the point at which the fitted line/ line of best fit crosses the $Y$-axis).

$\beta_{s,} \beta_{l}, \beta_{n}=$ Vector of the natural log of structural,locational and neighbourhhod characteristics respectively. 
Sij = Explanatory structural characteristics of a property.

Lij $=$ Explanatory locational charateruistics of a property.

$N i j=$ Explanatory neighbourhood characteristics of a property.

$z_{i j}=i$ is a random error and stochastic disturbance term (or unobserved

characteristics) that is expected to take the form of a normal

distribution with a mean of zero and a variance of $\alpha^{2}{ }_{e}$.

Section 3.1.1 discusses these characteristics in greater detail.

\subsubsection{Structural, neighbourhood and locational attributes in hedonic pricing}

Structural attributes according to Lombard, Behrens and Viruly (2017) are physical attributes of a building which speak to the quantitative and qualitative features associated with a certain property. Examples include its size, structural quality, and number of rooms. Neighbourhood attributes (neighbourhood municipal infrastructure) include publicly provided amenities or facilities in the environment in which the property is situated such as road developments, streetlights, and waste-disposal services. Locational characteristics (locational municipal infrastructure), according to Babawale and Johnson (2012) refers to the spatial/distance relationships to local services or landmarks in a neighbourhood. For example, proximity to a bus stop, or intercity train station. In studies like Parsons and Noially (2014) focus was in fact only on locational infrastructure - a mass transit system. Distances were measured in actual amounts as opposed to use of (distance intervals) found in studies like Babawale and Johnson (2012) and Famuyiwa amd Babawale (2014).

Further, the price of property is the sum of the implicit prices for each of its attributes. The estimation of these various attributes through the hedonic pricing necessitates their measurement (variable measurement). According to Belniak and Wieczorek (2017), information concerning significant attributes connected with the property such as number of rooms, etc, is important in order to make the estimation (hedonic) possible. These attributes could be measured in numerical terms and or binary terms as can be seen in Table 1. Johnson-Gardner (2007) describes such attributes as either 'value' variables or 'dummy' variables. The former is expressed in numerical quantities, or order of magnitude, and the latter (dummy variables) in binary (dichotomous) form. The dummy variable (on a binary/dichotomous scale) is commonly used when dealing with categorical variables in hedonic studies (Famuyiwa, 2019) - as categorical variables take on very limited spectra of values. Value variables on the other hand, take on actual quantities in numerical terms. So, in Table 1, variables 4 and 19 for example, are 'value' variables as they are measured in actual quantities. Variables 6 and 16 on the other hand are binary as they are categorised. Studies such as Weinberger (2001); Selim (2009), Johnson-Gardner (2007); Medda and Modelewska (2010); and Babawale and Johnson (2012) all followed this path. The binary scale is used to measure the availability of an attribute. For example, ' 1 ' if the municipal infrastructure available and ' 0 ' if unavailable to the property. Structural details such as number of rooms are measured in numerical or quantitative terms. Locational characteristics of property relating to geographic distance are measured in order of magnitude (in kilometres). 
The appropriateness of hedonic models is depicted in the demonstration of effective demand as opposed to projected perceptions of demand- which is illustrated through other environmental valuation techniques, such as contingent valuations surveys (Famuyiwa \& Babawale, 2014). Since the hedonic analysis reveals the financial impact of municipal infrastructure in property values, the unearned windfall gains (financial impact) can thus be taxed in accordance with the value contribution to property values. This thus reinforces the objectivity, equity and transparency of the LVC property tax system.

\subsection{Study area}

The basic purpose of this study is to demonstrate that a property tax rates schedule will anchor a fair monetary exchange for benefits-received from municipal infrastructure through property taxes. This is demonstrated by using a sample of properties in one of the 20 local government areas in Lagos state, Nigeria. The properties provide a basis or demonstrating the use of the tax rates schedule advanced. The local government picked for this purpose is Alimosho Local Government area, which is the most populous local government area in terms of both human population and amount of rateable properties. According to the Lagos Bureau of Statistics (2016) the area has a total number of 144,570 chargeable (rateable) properties and a land mass of approximately $183 \mathrm{~km} 2$.

\subsection{Study data}

The use and application of hedonic pricing requires some comparability of the population or sampling units in terms of property sub-markets. Straszheim (1974) submits that the property market is a series of single markets (property classes/types) which requires different hedonic functions. Bello and Bello (2007) add that in hedonic analyses, the skill of the valuer rests in the selection of comparable properties. According to So et al. (1997), a feasible approach to using the hedonic regression is to choose a sample with similar locational characteristics and income groups that are supposed to have homogeneous tastes so that the effects of various internal attributes and environmental characteristics of the neighbourhood are locationally insensitive. Therefore, this study used a sample of flats (apartments). Famuyiwa (2019) explains these to be residential accommodation with two or more bedrooms and its own conveniences within a building block. The reason for the use of flats was due to the relative accessibility to information and data on them in the study area. In any case the main idea behind the study is to demonstrate the potentials of the LVC property tax in Lagos State, Nigeria using a property sub-market, which in this case is residential apartments.

Data required for analyses of this nature are mainly primary in nature consisting of (i) annual rental values of properties under study, and (ii) characteristics or attributes that influence the value of properties significantly, namely 'Structural' attributes, 'Neighbourhood' attributes and 'Locational' 
attributes. The choice of these various attributes was elicited partly through the use of structured questionnaires in a pilot study designed based on guidance from previous similar studies. Such studies include Babawale, Koleoso, and Otegbulu (2012); Famuyiwa and Babawale (2014); Jimoh and Ige (2017). Physical observation was also used to determine municipal infrastructure available in the local government area. The researcher's experience in the area and the pilot study (which entailed physical observation) informed the choice of these attributes for inclusion in analyses. According to Field (2013), variable selection should be based on theoretical rationale and past research. Bello and Bello (2007) similarly submit that the skill of the valuer rests in the recognition of key variables. A field survey helped identify infrastructure available in the study area, as this information was not derivable through other means. This was used to identify the infrastructure variables used in the study. Additionally, these types of infrastructure feature significantly in other studies such as Babawale and Johnson (2012), Jimoh and Ige (2017).

In terms of the measurement of market property values, some studies adopt the use of capital/sales value, while others use annual rental values. Weinberger (2001) is specific with the use of rental rates owing to the fact that rental rates are more abundant and dynamic, thus more sensitive to changes in the market, allowing for more robust models. Famuyiwa (2018) explains that in the Lagos property market, this is particularly true, as Lagos is known to have a more active property rental market than its sales market. The rental values were provided by Estate surveyors and valuers operating in the locality, with the researcher in liaison.

Table 1 below shows the variables used for the study, their measurement indices, and their code. The variables comprise of a comprehensive set of attributes for the properties in question. As mentioned earlier, these variables for this class of properties (flats) were selected based on past research and theory.

Table 1: Definition of Regression Variables

\begin{tabular}{|c|l|c|c|c|}
\hline & Variables & $\begin{array}{c}\text { Variable } \\
\text { Code }\end{array}$ & Variable Specification/ Measurement & $\begin{array}{c}\text { Expected } \\
\text { Correlation } \\
\text { Coefficient Sign }\end{array}$ \\
\hline 1. & Annual Rental Value (PV) & RENT & In Nigerian currency (Naira) & + \\
\hline 2. & $\begin{array}{l}\text { Structural Quality of } \\
\text { Property }\end{array}$ & STRQUAL & Binary ('1' if good and '0' if otherwise) & + \\
\hline 3. & $\begin{array}{l}\text { State of Repair/ Condition of } \\
\text { Property }\end{array}$ & BCOND & Binary ('1' if good and '0' if otherwise) & + \\
\hline 4. & Number of Rooms & NROOM & Numerically specified & + \\
\hline 5. & Number of Bathrooms & BTHRM & Numerically specified & + \\
\hline 6. & Storage Space & STORE & Binary ('1' if adequately available, '0' if & + \\
\hline 7. & Finishes & FNSHS & Binary ('1' if good, and '0' if otherwise) & + \\
\hline 8. & Balcony & BALC & Binary ('1' if available, and '0' otherwise) & + \\
\hline 9. & Natural Ventilation & NVENT & Binary ('1' if good, and '0' if poor) & + \\
\hline
\end{tabular}




\begin{tabular}{|c|c|c|c|c|}
\hline 10. & Car Parking Space Capacity & CARP & Numerically specified & + \\
\hline 11. & $\begin{array}{l}\text { Neighbourhood Security } \\
\text { (Lagos neighbourhood safety } \\
\text { corps security agency) }\end{array}$ & NSEC & $\begin{array}{l}\text { Binary (' } 1 \text { ' if post is easily accessible and } \\
\text { ' } 0 \text { ' if otherwise). 'Easily accessible' in } \\
\text { terms of Neighbourhood security as a } \\
\text { variable is when the agency (i.e. the Lagos } \\
\text { neighbourhood safety corps security } \\
\text { agency) has at least a representative } \\
\text { available daily patrol on the street. }\end{array}$ & + \\
\hline 12. & Nature of Roads & ROAD & $\begin{array}{c}\text { Binary (' } 1 \text { ' if motorable and tarred and ' } 0 \text { ' } \\
\text { if not motorable and tarred) }\end{array}$ & + \\
\hline 13. & Pedestrian sidewalk & WALK & $\begin{array}{c}\text { Binary (' } 1 \text { ' if available and ' } 0 \text { ' if not } \\
\text { available) }\end{array}$ & + \\
\hline 14. & $\begin{array}{l}\text { Government waste disposal } \\
\text { service }\end{array}$ & WASTE & $\begin{array}{c}\text { Binary (' } 1 \text { ' if regular and available ' } 0 \text { ' if } \\
\text { not) }\end{array}$ & + \\
\hline 15. & Streetlights & SLIGHT & $\begin{array}{c}\text { Binary (' } 1 \text { ' if available and functional and } \\
\text { ' } 0 \text { ' if otherwise) }\end{array}$ & + \\
\hline 16. & Drainage & DRAIN & Binary (' 1 ' if good and ' 0 ' if poor) & + \\
\hline 17. & Street Cleaning & CLEAN & Binary (' 1 ' if available and ' 0 ' if otherwise & \\
\hline 18. & $\begin{array}{l}\text { Distance to main bus stop } \\
\text { (Transportation terminus) }\end{array}$ & BUSSTOP & In actual/geographic distance (km) & - \\
\hline 19. & $\begin{array}{l}\text { Distance to Local Retail } \\
\text { Market }\end{array}$ & DMRKT & In actual/geographic distance (km) & - \\
\hline 20. & $\begin{array}{l}\text { Distance to Primary Health } \\
\text { Care centre }\end{array}$ & DHOSP & In actual/geographic distance (km) & - \\
\hline 21. & $\begin{array}{l}\text { Distance to State Fire } \\
\text { Services }\end{array}$ & FIRE & In actual/geographic distance (km) & \\
\hline 22. & $\begin{array}{l}\text { Distance to Public Primary } \\
\text { School. }\end{array}$ & DSCHL & In actual/geographic distance $(\mathrm{km})$ & - \\
\hline 23. & $\begin{array}{l}\text { Distance to Local Police } \\
\text { Post/ Station }\end{array}$ & DPOLICE & In actual/geographic distance (km) & - \\
\hline
\end{tabular}

In Table 1, the first row shows the dependent variable, upon which the independent variables are regressed. Variables 2-23 are the independent variables of interest. Variables 2-10 are 'structural characteristics', while variables in rows 11-17 are 'neighbourhood characteristics' (neighbourhood infrastructure), and variables in rows 18-23 are 'locational characteristics' (locational infrastructure) of property. 'Neighbourhood' and 'locational' characteristics jointly represent municipal infrastructure. The 4th and 5th columns show their specification, measurement and expected coefficient signs.

A sample of 227 observations was considered appropriate based on Tabchnick and Fidell's (2001) formula. The formula takes into account the number of independent variables to be used as follows: $\mathrm{N}>50+8 \mathrm{~m}$ (where $\mathrm{m}$ is the number of independent variables, and $\mathrm{N}$ is the minimum number of observations required). However, this minimum required size of 227 was increased by $40 \%$ due to the expected problem of getting a low response rate. A total of 318 questionnaires were administered using the systematic random sampling as guided by Kothari (2004). This way, properties of interest (flats) were selected after some interval, whilst commencing from a randomly generated starting point. The intervals were at the discretion of the field 
assistants and the researcher. This was due to the fact that official information pertaining to the number of properties of interest, or even their geographic spread, was unavailable. Altogether, a total of 288 filled questionnaires were found useful, and whose data were then analysed with the aid of the Statistical Package for Social Sciences (SPSS) Version 22.0. Locational infrastructure with distance variables (variables in rows 18-23 in Table 1) were measured, using a handheld GPS device. Distances were determined in relation to locational infrastructure as used in Weinberger (2001). The use of Geographic Positioning Systems (GPS) in this study represents an advancement of previous studies on municipal infrastructure and property values in Lagos state, Nigeria. This innovation enabled much more infrastructure types to be considered, with much greater accuracy in terms of their measurement indices.

\section{Results and Findings}

Table 2 shows the descriptive statistics (mean values) of the property characteristics under study. The mean values are based on the measurement scales specified in Table 1. The variable 'RENT' is the dependent variable, while all other items listed in the first column are the independent variables. The mean values can be seen in the fourth column with standard deviation values in column 5 .

Table 2: Descriptive Statistics of Regression Variables

\begin{tabular}{|l|c|c|c|c|}
\hline $\begin{array}{l}\text { Variable } \\
\text { Code }\end{array}$ & Minimum & Maximum & Mean & $\begin{array}{c}\text { Standard } \\
\text { Deviation }\end{array}$ \\
\hline RENT & 200,000 & 650,000 & $418,007.261$ & 45.238 .835 \\
\hline STRQUAL & 0.000 & 1.000 & 0.890 & 0.449 \\
\hline BCOND & 0.000 & 1.000 & 0.693 & 0.161 \\
\hline NROOM & 2.000 & 4.000 & 2.885 & 1.520 \\
\hline BTHRM & 2.000 & 3.000 & 2.126 & 0.982 \\
\hline STORE & 0.000 & 1.000 & 0.502 & 0.114 \\
\hline FNSHS & 0.000 & 1.000 & 0.691 & 0.275 \\
\hline BALC & 0.000 & 1.000 & 0.453 & 0.096 \\
\hline NVENT & 0.000 & 1.000 & 0.928 & 0.377 \\
\hline CARP & 0.000 & 3.000 & 1.641 & 0.582 \\
\hline NSEC & 0.000 & 1.000 & 0.283 & 0.005 \\
\hline ROAD & 0.000 & 1.000 & 0.384 & 0.056 \\
\hline WALK & 0.000 & 1.000 & 0.257 & 0.072 \\
\hline WASTE & 0.000 & 1.000 & 0.397 & 0.158 \\
\hline SLIGHT & 0.000 & 1.000 & 0.225 & 0.529 \\
\hline DRAIN & 0.000 & 1.000 & 0.280 & 0.167 \\
\hline CLEAN & 0.000 & 1.000 & 0.138 & 0.049 \\
\hline BUSSTOP & 0.057 & 3.481 & 0.987 & 0.123 \\
\hline DMRKT & 0.219 & 4.700 & 1.211 & 0.475 \\
\hline DHOSP & 0.183 & 3.583 & 1.530 & 0.946 \\
\hline FIRE & 0.534 & 7.162 & 3.659 & 0.821 \\
\hline DSCHL & 0.226 & 4.095 & 4.764 & 0.558 \\
\hline
\end{tabular}




\begin{tabular}{|l|l|l|l|l|}
\hline DPOLICE & 0.298 & 2.291 & 3.005 & 0.610 \\
\hline
\end{tabular}

From Table 2, it is seen that the average distances to the main bus stop, local retail market, primary health care centre, fire station, public primary school and police station (collectively termed 'locational infrastructure') are 0.987 , $1.211,1.530,3.659,4.764$ and 3.005 kilometres $(\mathrm{km})$ respectively. For neighbourhood municipal infrastructure, average (mean) values are 0.283, $0.384,0.257,0.397,0.225,0.280,0.138 \mathrm{~km}$ for security, motorable roads, pedestrian sidewalk, waste disposal services, streetlights, drainage and street cleaning respectively. This shows that $28.3 \%$ of properties are easily accessible to the Lagos neighbourhood safety corps (LNSC) security services. This agency (LNSC) is a motorized patrol agency that moves around neighbourhoods and ensure safety of communities. This creates a sense of security amongst residents. Their daily presence on various streets serve to deter and prevent the incidence of crime. What is meant by 'easily accessible' are properties that have at least a representative available daily on duty on the street where it is located. Of the surveyed properties, $38.4 \%$ have tarred and motorable roads leading up to them and $25.7 \%$ have proper sidewalks leading up to them. In terms of services, 39.7\% dispose of their domestic waste through the Lagos state waste management authority. In terms of services, $39.7 \%$ dispose of their domestic waste through the Lagos state waste management authority. Functioning streetlights are available to only $22.5 \%$ of properties in the study area. While $28 \%$ of the properties have good public drainage outlets, and $13.8 \%$ enjoy public street cleaning. This shows that a lesser amount of properties enjoys services optimally or have access to them at all. Regarding the 'standard deviation', the values are low, showing that the spread of the individual values around the 'mean' is low. The standard deviation is the most widely used tool to determine how close or far away the individual values in a data set are, from a central representative value (such as the mean). In this instance the low standard deviation value shows that the individual values are clustered around the mean. All these descriptive values feed into the regression analyses and outcome.

In Table 3, the hedonic regression results show the implicit prices (coefficients) of the various property characteristics, as estimated in the annual rental values. These are the influences of property characteristics including municipal infrastructure, in property rental values.

Table 3: Hedonic Regression Results

\begin{tabular}{|c|l|c|c|c|c|c|}
\hline \multicolumn{2}{|l|}{ Model } & \multicolumn{2}{|c|}{$\begin{array}{c}\text { Unstandardised } \\
\text { Coefficients }\end{array}$} & $\begin{array}{c}\text { Standardised } \\
\text { Coefficients }\end{array}$ & \multirow{2}{*}{ t. } & \multirow{2}{*}{ Sig. } \\
\cline { 3 - 5 } & B & $\begin{array}{c}\text { Std. } \\
\text { Error }\end{array}$ & Beta & & \\
\hline 1 & (Constant) & 11.592 & 4.904 & & 2.3638 & .0089 \\
\hline & STRQUAL & .2114 & .0984 & .2347 & 2.1484 & .0000 \\
\hline & BCOND & .1395 & .0452 & .1310 & 3.0863 & .0000 \\
\hline & NROOM & .1979 & .0300 & .1528 & 6.5967 & .0230 \\
\hline & BTHRM & .0748 & .0137 & .0803 & 5.4599 & .0256 \\
\hline & STORE & .0462 & .0517 & .0572 & .8936 & .0337 \\
\hline
\end{tabular}




\begin{tabular}{|l|l|c|c|c|c|c|}
\hline & FNSHS & .0923 & .0076 & .0719 & 12.1447 & .0028 \\
\hline & BALC & .0691 & .0050 & .0654 & 13.8200 & .0195 \\
\hline & NVENT & .0837 & .0100 & .0755 & 8.3700 & .0072 \\
\hline & CARP & .0885 & .0051 & .0918 & 17.3529 & .0003 \\
\hline & NSEC & .0332 & .0093 & .0204 & 3.5698 & .0695 \\
\hline & ROAD & .0494 & .0196 & .0386 & 2.5204 & .0086 \\
\hline & WALK & .0396 & .0968 & .0507 & .4091 & .0000 \\
\hline & WASTE & .0099 & .0034 & .0040 & 2.9118 & .0016 \\
\hline & SLIGHT & .0188 & .0050 & .0116 & 3.7600 & .0450 \\
\hline & DRAIN & .0272 & .0028 & .0039 & 9.7143 & .0028 \\
\hline & CLEAN & .0056 & .0128 & .0051 & .4375 & .0414 \\
\hline & BUSSTOP & -.0221 & .0005 & -.0262 & -44.2000 & .0366 \\
\hline & DMRKT & -.0089 & .0072 & -.0027 & -1.2361 & .0276 \\
\hline & DHOSP & -.0130 & .0370 & -.0230 & -.3514 & .0118 \\
\hline & FIRE & -.0009 & .0156 & -.0045 & -.0577 & .0132 \\
\hline & DSCHL & -.0009 & .0052 & -.0010 & -.1731 & .0000 \\
\hline & DPOLICE & -.0034 & .0325 & -.0016 & -.1046 & .0001 \\
\hline
\end{tabular}

In Table 3, the column tagged 'unstandardised coefficients' are only used to build the regression equation - as seen below. However, for making inferences about implicit prices, the 'standardised coefficients' are used (Pallant, 2005). The estimated equation for a hedonic regression model, in a semi-logarithmic form, is expressed as follows:

$\mathbf{P N}=11.592+0.2114$ STRQUAL $+0.1395 \mathrm{BCOND}+0.1979 \mathrm{NROOM}+$ $0.0748 \mathrm{BTHRM}+0.0462 \mathrm{STORE}+0.0923 \mathrm{FNSHS}+.0691 \mathrm{BALC}+$ $.0837 \mathrm{NVENT}+.0885 \mathrm{CARP}+0.0332 \mathrm{NSEC}+0.0494 \mathrm{ROAD}+$ $0.0396 \mathrm{WALK}+0.0099 \mathrm{WASTE}+0.0188 \mathrm{SLIGHT}+0.0272 \mathrm{DRAIN}+$ 0.0056CLEAN - 0.0221BUSSTOP - 0.0089 DMRKT - 0.0130DHOSP 0.0009FIRE - 0.0009DSCHL - 0.0034DPOLICE

From Table 3, above it can be inferred that if neighbourhood security of Lagos state is easily accessible to a property in the study area, its rental value will increase by $2.04 \%$. If the road surface is motorable and tarred, the annual rental value of a property will increase by $3.86 \%$. The availability of pedestrian sidewalks will increase property value by $5.07 \%$. The reason for this value may be due to the desirability of residents to taking walks or going jogging. Available and regular government waste disposal services will increase property value by $0.4 \%$. Available and functioning streetlights will increase property value by $1.16 \%$. Good drainage will increase the value of a property by $0.39 \%$.

For locational municipal infrastructure, with every $1 \mathrm{~km}$ decrease in distance to the bus stop, property value will increase by $2.62 \%$. And with every $1 \mathrm{~km}$ increase in distance to the fire service station, property rental value will decrease value by $0.45 \%$. For primary health care centres, property values will increase by $2.30 \%$ for every decrease in distance by $1 \mathrm{~km}$. This means that proximity and closeness to various locational municipal infrastructure 
influence property values positively. The influence of structural characteristics on property values can also be interpreted in similar fashion from the standardised coefficient column. However, analysing the structural components is not within the scope of this study. The T-statistics (column tagged ' $t$ ') and their probability values ('sig.' column) show the significance of each independent variable. Essentially, the values in the column tagged 'Sig' help determine whether the influences observed are significant. All these are significant at $0.05(5 \%)$ with the exception of 'neighbourhood security' whose significance is ' 0.0695 '. This is perhaps due to private security measures taken by residents locally, such as private security personnel. Usually, when the significance is less than the threshold (in this case, 0.05), the hypotheses that each individual influence of the attributes is significant in the property values, is accepted. While 'T-statistics' are produced for the individual variable (Pallant, 2005) and their respective levels of significance as seen in Table 3, the 'F-statistic' is produced from an Analysis of Variance (ANOVA) test. The T-statistics show the significance of each independent variable, while the F-statistic, is for the overall significance of the model.

Generally, these results support similar studies like Sirmans, Macpherson and Zietz (2005) where a careful consideration of variables suggests that structural variables of property are more dominant, with some of the highest coefficient values such as $0.2347,0.1528,0.131$ for structural quality, number of rooms, and state of repair respectively. Municipal infrastructure (both neighbourhood and locational characteristics of property) generally represents a lesser proportion of property values than structural attributes do, for obvious reasons. From Table 3, municipal infrastructure (coefficients of both neighbourhood and locational attributes aggregated) are generally lower in value- about 0.1933 than the aggregated value of the coefficients of structural attributes . Though the coefficient values are essentially interpreted as the individual percentage change in rental values for a given variable), these individual percentage changes in rental values can be aggregated, in order to have an insight as to the weight of their joint influences in rental values. In this case, 0.1933, and it is upon this joint influence that the LVC property tax will thus be largely based. The results (coefficient values) support similar studies like Babawale and Johnson (2012); and Babawale, Koleoso and Otegbulu (2012).

The results in Table 3 will later be used to help guide a tax schedule based on the impact of municipal infrastructure. The application of this tax schedule expectedly, covers only the coefficients related to municipal infrastructure i.e. 'neighbourhood characteristics' (neighbourhood municipal infrastructure), and 'locational characteristics' (locational municipal infrastructure) variables listed in rows 11-17 and 18 -23 respectively. The tax burden would therefore be based on results so derived from the coefficients in rows 11-17 and 18-23, tagged 'standardised coefficients' as 'capturing back value' because these are the implicit prices of municipal infrastructure, in property values (the financial contributions that various municipal infrastructure have on property values). Each coefficient value (in the Standardised coefficients column) is interpreted as the average change in the property price, relative to 
a per unit change in the corresponding independent variable while holding other variables in the model constant.

Table 4: Model Summary ${ }^{b}$

\begin{tabular}{|l|c|c|c|c|}
\hline Model & R & R-Square & $\begin{array}{c}\text { Adjusted R } \\
\text { Square }\end{array}$ & $\begin{array}{c}\text { Std. Error of } \\
\text { the Estimate }\end{array}$ \\
\hline 1 & $.953^{\mathrm{a}}$ & .909 & .902 & 89301.882 \\
\hline
\end{tabular}

a Predictors: (Constant), DPOLICE, DSCHL, FIRE, DHOSP, DMRKT, BUSSTOP, CLEAN, DRAIN, SLIGHT, WASTE, WALK, ROAD, NSEC, CARP, NVENT, BALC, FNSHS, STORE, BTHRM, NROOM, BCOND, STRQUAL

${ }^{b}$ Dependent Variable: Annual Rental Value in Naira

Table 4 shows the performance of the hedonic regression (model summary). It can be seen that the model (hedonic) explains $90.9 \%$ of variance in the rental values which is desirable as this statistic is high. This can be read from the 'R-square' column, suggesting that $90.9 \%$ of the variation in rental values in the study area is explained by the twenty-two explanatory variables employed in the model. In hedonic analyses, models with good fits are at least higher than the 60\% R2 threshold value (Pallant, 2005). The predictive performance of the model is also good as indicated by adjusted $\mathrm{R}^{2}$ value of $90.1 \%$. These statistics indicate that the model is reasonably fit for making inferences. Table 5 shows the ANOVA results. These results assess the overall statistical significance of the results, as indicated by the significance of the F-statistic (.000). It determines if the joint influence of the independent variables in the model is statistically significant in the dependent variable (rental value) (Famuyiwa, 2019). From the column tagged 'Sig.' it can be seen that it is statistically significant, as $\mathrm{P}<0.005(\mathrm{P}=0.000)$. This is as recommended by Pallant (2005).

Table 5: ANOVA ${ }^{b}$

\begin{tabular}{|l|l|c|c|c|c|c|}
\hline Model & & Sum of Squares & Df & Mean Square & F & Sig. \\
\hline \multirow{4}{*}{1} & Regression & 21096546975364.045 & 22 & 958933953425.638 & 120.245 & $.000^{\mathrm{a}}$ \\
\cline { 2 - 7 } & Residual & 2113328958782.681 & 265 & 7974826259.557 & & \\
\cline { 2 - 7 } & Total & 23209875934146.726 & 287 & & & \\
\hline
\end{tabular}

The regression results show that a significant portion of the value of flats in the study are attributable to municipal infrastructure. This lays the foundation of evidence to develop a tax schedule that can be used by local governments to reclaim some of the value created by their efforts.

\section{Rates Schedule}

This section answers the second research question regarding how the pricing effects of municipal infrastructure can be captured as a basis for property taxation. In capturing value in this study, deference is made to the coefficients in Table 3 (calculation of value/financial contributions of municipal infrastructure to property values) - as discussed in subsection 2.5 of this paper. The assumption here is that the value capture tax rate would altogether 
be largely a percentage of the property value, formed of the contributory influences of various municipal infrastructure on property values.

\subsection{Rates schedule for locational characteristics (municipal infrastructure)}

It can be expected that property characteristics measured in distance (locational characteristics) would have varying influences on property prices as a result of proximity. Parsons and Noially (2004) explain that those who benefit most from a distance-based infrastructure project are those who reside closest to it. Though disamenity (negative) effects of infrastructure have been recorded in studies, these have been in relation to high scale infrastructure such as railway termini, or airports (Kilpatrick et al,, 2007; Seo, 2016). In Nigeria, municipal infrastructure and real estate pricing studies significantly show positive relationships between infrastructure and property values at the neighbourhood level. (Babawale et al., 2012; Famuyiwa \& Babawale, 2014; Liman et al., 2015). Effects are thus expectedly positive, based on a priori expectations. According to Korngold (2017) due to the capitalised proximity value, these benefits arise depending on proximity of a property to the infrastructure. Thus, tax systems of this nature impose proportionately higher rates on properties closer to the specific infrastructure. From this, the researcher recommends the use of 'banding' of properties - in terms of proximity to specific locational characteristics (locational municipal infrastructure). Properties are classified according to their distance intervals, into 'bands' from various locational infrastructure. As such, they are grouped accordingly, where distances are fragmented into not more than 4 bands (or stretches) of $1 \mathrm{~km}$ each as seen in Table 6. Based on the studies of Parsons and Noially (2004) it is argued that implicit prices of locational infrastructure in property values would decline steadily and proportionately with increase in distance to specific locational infrastructure and vice versa. This banding schedule makes the LVC tax even more equitable in the sense that the tax liability and locational municipal infrastructure benefits are even further aligned. 'Banding' addresses the imbalance that arises from the proximity edge to locational infrastructure that properties have over each other. Properties closer to the locational infrastructure in question tend to have higher proximity value, which this banding schedule takes into account, in LVC tax rates.

Table 6: Definition of Bands

\begin{tabular}{|l|c|}
\hline Description of Bands & Distance to Locational Characteristic (Municipal Infrastructure) \\
\hline Band 1 (B1) & Up to a 1-kilometer distance to a specific locational characteristic \\
\hline Band 2 (B2) & More than 1, and less $2 \mathrm{~km}$ to specific locational characteristic \\
\hline Band 3 (B3) & More than 2 and less than $3 \mathrm{~km}$ to specific locational characteristic \\
\hline Band 4 (B4) & More than 3 and up to $4 \mathrm{~km}$ to specific locational characteristic \\
\hline
\end{tabular}

Every property is located in a Band, (B1, B2, B3, or B4). If more than $4 \mathrm{~km}$, the logical progression will terminate at zero. Thus, the influence of a locational infrastructure located more than $4 \mathrm{~km}$ from a property is regarded as 'zero' for that property. For properties in B1 to B4, the multiplier of a 
regression coefficient in a particular zone will decrease proportionately. The rationale for using 1-km 'intervals' in Table 5 is that from the average results in Table 3 most distances are not more than $4 \mathrm{~km}$ and, in any case, the value of the implicit price would have declined significantly after $4 \mathrm{kms}$.

$$
\text { Therefore: } \mathrm{B} 1>\mathrm{B} 2>\mathrm{B} 3>\mathrm{B} 4>0 \text {. }
$$

Where: 'B1' as a multiplier, applied to locational infrastructure coefficients would be equal to ' 1 '

$B 2=B 1 / 2($ i.e. $1 / 2)$

$B 3=B 1 / 3$ (i.e. $1 / 3$ )

$B 4=B 1 / 4$ (i.e. $1 / 4$ )

Any distance after B4, would be regarded as zero.

The influence of Locational infrastructure is represented as 'L1, L2, L3, $\mathrm{L} 4, \ldots \mathrm{LN}$, where $\mathrm{L}$ is derived from the regression coefficients for locational infrastructure. Each infrastructure is treated individually, and on the basis of how much it influences property values accordingly. For example, being within $1 \mathrm{~km}$ (Band 1) of the local fire station means a property will increase in value by $0.09 \%(-.0009)$ as seen in Table 3 . The further away (every $1 \mathrm{~km})$ the property is from a specific locational infrastructure, the lesser the value influence of that infrastructure will be on a property's value proportionately. Hence this is also reflected in rates. In this instance (using the guidance on bands above) the value influence of the fire station for a property in Band 2, will be $1 / 2$ of $0.09 \%$ (i.e. $0.045 \%$ ). $\mathrm{N}$ represents the amount of locational infrastructure identified for LVC tax purposes in any local government area. In this case, $\mathrm{N}=6$ (variables in rows 18-23 in Table 1). 'L1' for instance, would be the regression coefficient (implicit price) for locational infrastructure for 'Bus stop'. For any property in Band 1 for example, the tax burden for locational infrastructure would therefore be represented as follows:

$$
\sum \mathrm{LB}=(\mathrm{L} 1 \mathrm{~B} 1+\mathrm{L} 2 \mathrm{~B} 1+\mathrm{L} 3 \mathrm{~B} 1 \ldots+\mathrm{LNB} 1)
$$

The implicit price of each locational infrastructure coefficient would be estimated on the basis of its the proximity to the property in question (i.e. based on the Band the property falls into. Either B1, B2, B3 or B4). So, for a property which falls into different bands by virtue of its proximity to locational infrastructure:

\section{$\sum \mathrm{LB}$ becomes $\sum(\mathrm{LNBX})$}

Where $\mathrm{X}$ is the denominator of the band a property might fall in, in relation to the specific locational infrastructure- ranging from $1-4$. The value of ' $\mathrm{BX}$ ' could therefore be $1,1 / 2,1 / 3$ or $1 / 4$.

\subsection{Schedule for neighbourhood characteristics (municipal infrastructure)}

The derivation of rates on the basis of the influence of neighbourhood characteristics on real estate values is more direct than for locational characteristics. Thus, the hedonic price function is represented as $\beta \mathrm{Nij}$. 
Hence, rates would be based on the summation of coefficients that fall under this category as follows:

$$
\sum \beta \mathrm{Nij}=\beta \mathrm{Nij} 1+\beta \mathrm{Nij} 2+\beta \mathrm{Nij} 3+\beta \mathrm{Nij} 4+\ldots \beta \mathrm{Nijn}
$$

For the purpose of rates, a simple equation $-\sum \mathrm{NI}$ is derived. Where NI stands for 'Neighbourhood Infrastructure'. $\sum \mathrm{NI}=(\mathrm{NI} 1+\mathrm{NI} 2+\mathrm{NI} 3 \ldots+\mathrm{NIz})$. The grouping of property into bands is not applied here, since the proximity factor is not used in the hedonic regression coefficients for neighbourhood infrastructure.

\subsection{Value capture property tax schedule}

The ultimate schedule altogether is carried out in 3 steps - similar to Parsons and Noially (2004). First stage is the hedonic regression analyses of the implicit prices of property characteristics (independent variables) on property rental values (dependent variable) as seen in subsection 3.4 (Table 3). Next, the tax index is created, which encompasses the implicit prices of significant neighbourhood infrastructure, and locational infrastructure as explained in subsection 4.1 and 4.2. Hence the tax index is ' $\sum(\mathrm{LNBX})+\sum \mathrm{NI}$ ' for locational and neighbourhood infrastructure, as a representation (implicit prices) of municipal infrastructure in property values.

Thirdly, the entire tax burden is proposed, which takes into consideration the following:

(a) Property (annual rental) values denoted as ' $\mathrm{P}$ '.

(b) Implicit prices of municipal infrastructure in property values denoted as ' $\sum$ (LNBX) $\mathrm{P}+\sum(\mathrm{NI}) \mathrm{P}$.

(c) An additional amount may (in some cases) may be required to augment revenue from the LVC tax, to support budget requirements from the property tax, by the authorities. Such as a constant charge applicable to all rateable properties regardless, is denoted as ' $\mathrm{C}$ '.

(d) Any other criteria deemed necessary by the authorities such as a rateable value (percentage of property value that can be taxed), denoted as 'RV'.

This tax schedule thus is given as: $\left\{\sum(\mathrm{LNBX}) \mathrm{P}+\sum(\mathrm{NI}) \mathrm{P}+\mathrm{C}\right\} \mathrm{RV}$.

For bare (undeveloped) land, which has not been discussed so far, as a matter of policy, the application could comprise of the additional amount explained in (c) above- the minimum constant sum which would help discourage land speculation. This can be applied by government, only where this is deemed necessary.

\section{Concluding Comments}

In light of the poor state of infrastructure, and the dire need for reform, this study set out to develop an LVC rates schedule for Lagos state, Nigeria, in order to aid sustainability in financing municipal infrastructure. The study 
argues that there are varying influences of municipal infrastructure on property values, and this should be reflected in property tax rates. This is demonstrated using the largest local government in Lagos; Alimosho Local Government area. Using the hedonic regression analysis, the financial influences of municipal infrastructure are revealed to have significant positive impacts on real estate values. This confirms the long-standing notion that municipal infrastructure has substantive effects on real estate pricing. From the regression results, an LVC property tax rates schedule is developed based on the influences of infrastructure on property values. Rates therefrom are thus considered equitable as they are aligned with the benefits received from infrastructure services. This approach in setting of LVC property tax rates has not been taken into consideration in the existing property tax system in Nigeria, and is recommended for use in Lagos. Also recommended is the enablement and empowerment of local government areas in the state, due to their critical role in effectively implementing the recommended tax rates schedule. Clear policy intent on property rates, entrenched in the LVC concept must also be well established. If the critical relationship between infrastructure and property values is entrenched as a fundamental basis for assessing property taxes, it will appreciably improve equity in the property tax system, creating compliance and revenue buoyancy. Optimally provided infrastructure thus implies higher tax revenues for government and enhances economic empowerment by way of cost savings gained from reduced expenditure on private provision of services. As mentioned in the second section of this paper (2.1) revenue generation in property taxation is highly linked with improved infrastructure spending. This will engender reform in the infrastructure sector in Lagos state.

\section{References}

Abbott, D. (2008). Encyclopaedia of real estate terms (3rd edition). London: Delta Alpha Publishing.

Adegbenjo, A. (2003). Property identification as a tool for reforming property tax in Nigeria. In Omirin, M.M., Nubi, T. \& Fawehinmi, S.A.(Eds.) Land Management and Property Tax Reform in Nigeria-Proceedings of a National Workshop organised by the Department of Estate Management, University of Lagos. pp 374-385.

Agwu, A.N. (2019). The new NFIU policy guidelines and morality of local government fiscal autonomy in Nigeria. [Online]. Available at https://www.connecteddevelopment.org/the-new-nfiu-policyguidelines-and-morality-of-local-government-fiscal-autonomy-innigeria (Accessed: 26th September, 2019).

Ahmad, E., Brosio,G. \& Pöschl, C. (2014). Local property taxation and benefits in developing countries - overcoming political resistance? Asia Research Centre Working Paper 65. [Online]. Available at http://www.lse.ac.uk/asiaResearchCentre/ files/ARCWP65AhmadBrosioPoeschl.pdf (Accessed: 1st May, 2016).

Ajayi, M.T.A., Kemiki, O.A., Muhammed, J.K., Adama, U.J. \& Ayoola, A.B. (2015). A study of the application of GIS in the assessment of the impact of infrastructure on residential property value in Minna. In 
proceedings of the 21st Annual Pacific Rim Real Estate Society Conference, 18-21st January. Kualarlumpur, Malaysia.

Ali, M., Fjeldstad, O. \& Katera, L. (2017). Property taxation in developing countries. CHR Michelsen Institute CMI Brief 16 (1). [Online]. Available at https://www.cmi.no/publications/6167-propertytaxation-in-developing-countries (Accessed: 11th February, 2018).

Arimah, B.C. (1992). Hedonic prices and the demand for housing attributes in a third world city: the case of Ibadan, Nigeria. Urban Studies, 29(5), pp.639-651.

Babawale, G.K. \& Johnson, O. (2012). The specification of hedonic indexes for duplexes in Lekki peninsular area of Lagos metropolis. Elixir Social Science Journal, 45, pp.7689-7698.

Babawale, G.K. \& Nubi, T.G. (2011). Property tax reform: an evaluation of Lagos State land use charge, 2001. International Journal of Law and Management, 53(2), pp.129-148.

Babawale, G.K., Koloeoso, M. \& Otegbulu, A.C. (2012). A hedonic model for apartment rentals in Ikeja area of Lagos metropolis. Mediterranean Journal of Social Sciences, 3(3), pp.109-120. DOI: 10.5901/mjss.2012.v3n3p109.

Bello, M.O. \& Bello V.A. (2008). Willingness to pay for better environmental services: evidence from the Nigerian real estate market. Journal of African Real Estate Research, 1(1), pp.19-27.

Belniak, S. \& Wieckorek, D. (2017). Property valuation using hedonic price method - procedure and its application. Semantic scholar. [Online]. Available at https://www.semanticscholar.org/paper/PropertyValuation-using-Hedonic-Price-Method---and-BelniakWieczorek/99e9f9c97960fec7f0bb5c137778a69563f4ffad (Accessed: 9th August, 2020).

Berniaz, K. (2009). Municipal property tax in BC: Principles and provincial strategies to shape local tax distribution policy. Advanced Management Report Prepared for: Ministry of Community and Rural Development Available at:

https://dspace.library.uvic.ca/bitstream/handle/1828/1909/berniaz ka te.pdf? sequence $=1 \&$ is Allowed $=y$ (Accessed: 26th August, 2018).

Bhattacharjee, A. \& DeCastro, E. A. (2011). Spatial Interactions in hedonic pricing models: The Urban Housing Market of Aveiro, Portugal. Dundee Discussion Papers in Economics, pp.1-44.

Biitir, S.B. (2019). Designing Land Value Capture Tools in the Context of Complex Tenurial and Deficient Land Use Regulatory Regimes in Accra, Ghana. Working Paper WP19SB1. Lincoln Institute of Land Policy.

Brown-Luthango, M. (2010). Capturing land value increment to finance infrastructure investment - possibilities for South Africa. Urban Forum, 22(1) pp.37-52.

Chapman, J. (2016). Value capture taxation as an infrastructure funding technique. Public works, management and policy, 22(1), pp.31-37.

Collier, P., Glaeser, E., Venables, T., Blake,M. \& Manwaring, P. (2018) Land and property taxes for municipal finance. London: International growth centre. 
Djankov, S. \& Nasr, J. (2020). Tax relief in a time of crisis: what countries are doing to sustain business and household liquidity. Washington: World Bank. [Online]. Available at: https://blogs.worldbank.org/developmenttalk/tax-relief-time-crisiswhat-countries-are-doing-sustain-business-and-household (Accessed: 10th December, 2020).

Dunse, N. \& Jones, C. (1998). A hedonic price model of office rent. Journal of Property Valuation and Investment, 16(3), pp.297-312.

Famuyiwa, F. (2018). Natural environmental amenities and house prices - a hedonic analysis for integrated planning. Journal of African Real Estate Research, 3(2), pp.44-62.

Famuyiwa, F. (2019). Implicit pricing of municipal infrastructure in real estate values for property tax equity. Unpublished Doctoral Dissertation. Department of Estate Management, University of Lagos.

Famuyiwa, F. (2020). COVID-19 and Innovative Infrastructure Finance: Adapting the Land Value Capture Tax for Lagos State, Nigeria. In Proceedings of Land-based taxation for infrastructure finance in a post COVID-19 ERA. The Centre for Housing and Sustainable Development, University of Lagos. 29th September.

Famuyiwa, F. \& Babawale, G.K. (2014). Hedonic values of physical infrastructure in house rentals. Facilities Management, 12(3), pp.211230.

George, H. (1879). Progress and poverty. New York: Robert Schalkenbach Foundation.

Germán, L. \& Bernstein A.E. (2018). Land value capture tools to finance or urban future (policy brief). Lincoln Institute of Land Policy. [Online]. Available at:

https://www.lincolninst.edu/sites/default/files/pubfiles/land-valuecapture-policy-brief.pdf (Accessed: 20th July, 2020).

Haas, A.R.N (2017). Property taxes: exploring the untapped potential for the city of Hargeisa. London: International growth centre. Available at: https://www.theigc.org/wpcontent/uploads/2018/02/201712HargeisaPropertyTaxWP_Final3.pd f (Accessed: 5th October, 2020).

Haas, A.R.N. (2019). Capturing the value: the opportunities and challenges of land value capture instruments for cities. [Online]. Available at: https://www.theigc.org/wp-content/uploads/2019/04/Capturing-thevalue.pdf (Accessed: 20th October, 2020).

Huston, S.H. \& Lahbash, E. (2018). Land value capture and tax increment financing: overview and considerations for sustainable urban investment. European Journal of Sustainable Development Research, 2(3), pp.1-9.

Ibrahim, O.R. \& Fosudo, O.P. (2017). New option for urban infrastructure financing in Nigeria: unlocking of land values. In proceedings of the 2nd International Conference of Environmental Studies, Moshood Abiola Polytechnic Abeokuta, Ogun State, Nigeria.

Ikpefan,O., Ailemen, A. \& Akande, O.A. (2010). Vision 20-2020: imperatives of infrastructure financing. Journal of Social and Management Sciences Review, 5(2), pp.35-46. 
Institute on Taxation and Economic Policy. (2011). How property taxes work. Washington: ITEP. [Online]. Available at: https://itep.org/howproperty-taxes-work/ (Accessed: 11 th September 2020).

Istrate, E. \& Puentes, R. (2011). Moving Forward on Public Private Partnerships: U.S. and International Experience with PPP Unit. Brookings-Rockefeller Project on State and Metropolitan Innovation. Available at: https://www.brookings.edu/wpcontent/uploads/2016/06/1208 transportation_istrate puentes.pdf (Accessed: 11th December, 2020).

Jimoh, D.A. \& Ige, V.O (2017). Public infrastructure vs. residential property rental value in Lagos, Nigeria. Journal of sustainable development studies, 10(1), pp.17-33.

Johnson-Gardner (2007). An assessment of the marginal impact of urban amenities on residential pricing. Reconnecting America. [Online]. Available at:

http://www.reconnectingamerica.org/assets/Uploads/JohnsonGardne r-Urban-Living-Infra-Research-Report.pdf (Accessed: 3rd May, 2012).

Kilpatrick, J.A., Throupe, R.L., Carruthers, J.I. \& Krause, A. (2007). The impact of transit corridors on residential property values. The Journal of Real Estate Research, 29(3), pp.303-320.

Korngold, G. (2017). The potential for value capture as a revenue raising tool in the United States. Lincoln Institute of Land Policy. [Online]. Available at:

https://www.lincolninst.edu/sites/default/files/sources/events/korngo ld presentation_lincoln_revised.pdf (Accessed: 16th April 2020).

Lagos State Government. (2011). Lagos State Public Private Partnership Law of 2011. Lago State. [Online]. Available at:

https://awnigeria.com/2019/10/public-private-partnership-law-oflagos-state/ (Accessed: 10th of December, 2020).

Lagos State Government. (2020). Lagos Neighbourhood Safety Corps (LNSC). Lagos State Government. [Online]. Available at: https://lsstf.lagosstate.gov.ng/lagos-neighborhood-safety-corpslnsc/ (Accessed: 10th December, 2020).

Li, X. \& Love, P.E.D. (2019) Employing land value capture in urban rail transit public private partnerships: Retrospective analysis of Delhi's airport metro express. Research in Transportation Business \& Management, 32, 100431.

Lincoln Institute of Land Policy. (2019). Value capture and the property tax. Lincoln Institute of Land Policy. [Online]. Available at: https://www.lincolninst.edu/key-issues/value-capture-property-tax (Accessed: 2nd March, 2020).

Lombard, S., Behrens, R. \& Viruly, F. (2017). Value creation around transport infrastructure in South Africa: the case of Gautrain. In proceedings of the 36th Southern African Transport Conference, 10$13^{\text {th }}$ July, Pretoria, South Africa.

Malpezzi, S. (2002). Hedonic pricing models: a selective and applied review. In Housing Economics and public policy. T. Sullivan \& K. Gibb (Eds). Oxford: Blackwell Science Limited. 
McGaffin, R., Kirova, M., Viruly, F. \& Michell, K (2016). Value Capture in South Africa - a way to overcome urban management challenges and unlock development opportunities? Urban Real Estate Research Unit. [Online]. Available at:

www.ureru.uct.ac.za/sites/default/files/image tool/images/383/Valu e\%20Capture \%20in\%20South\%20Africa \%20\%282016\%29\%20UR ERU\%20Report.pdf (Accessed: 9th August, 2020).

McGaffin, R., Napier, M. \& Gavera, L. (2014). Value capture in South Africa- conditions for their successful use in the current legal context. Urban Forum 25(3), pp.375-38.

McGaffin, R., Viruly, F. \& Boyle, L. (2019). An investigation into the use of land-based financing to fund infrastructure in South Africa. Journal of Property Investment and Finance. DOI: 10.1108/JPIF-02-20190016.

McIntosh, J., Trubka, R., Newman, P. \& Kenworthy, J. (2017). Framework for land value capture from investments in transit in car-dependent cities. The Journal of Transport and Land Use, 10(1), pp.155-185.

Medda, F.R. \& Modelewska, M. (2011). Land value capture as a funding source for urban investment: the Warsaw metro system. Ernst \& Young. [Online]. Available at:

https://www.ey.com/Publication/vwLUAssets/Land value capture as a funding source for urban investment.pdf/\$FILE/Land value capture as a funding source for urban investment.pdf

(Accessed: 9th July, 2014).

Ministry of Urban Development, Government of India. (2017). Value capture finance policy framework. Ministry of Urban Development. [Online]. Available at: https://smartnet.niua.org/sites/default/files/resources/VCF\%20Policy \%20Book FINAL.pdf (Accessed: 14th September, 2020).

Neville, J.T. (2016). Modelling a land value capture application in Christchurch, New Zealand. Master's Dissertation. University of Canterbury, New Zealand.

Nzioki, P. \& Osebe, P. (2014). Analysis of factors affecting tax compliance in real estate sector: a case of real estate owners in Nakuru town, Kenya. Research Journal of Finance and Accounting, 5(11), pp.1-12.

Ogbuefi, J.U. (2004). Comparative property rating and taxation. Institute for Development Studies. Enugu: University of Nigeria.

Otegbulu A. (2010). An assessment of user-demand preference of urban infrastructure in Lagos metropolis using the contingent valuation model. Unpublished Doctoral Dissertation. Department of Geography and Meteorology, Enugu State University.

Oualalou, F. (2012). Land value capture: a method to finance urban investments in Africa? Committee on Local Finance for Development, Dakar.

Pallant, J. (2005). SPSS survival manual: a step by step guide to data analysis using SPSS. Routledge.

Parsons, G.R. \& Noailly, J. (2004). A value capture property tax for financing beach nourishment projects: an application to Delaware's open beaches. Ocean and Coastal Management, 47(1-2), pp.49-61. 
Prichard, W. (2017). Linking property tax revenue and public services. International Centre for Tax and Development at the Institute of Development Studies summary brief number 13. [Online]. Available at: https://www.ictd.ac/publication/linking-property-tax-revenuepublic-services/ (Accessed: 5th of August, 2019).

Rosen, S. (1974). Hedonic prices and implicit markets: product differentiation in pure competition. The Journal of Political Economy, 82(1), pp.3455.

Selim, S. (2009). Determinants of house prices in Turkey: a hedonic regression model versus artificial neural network. Expert systems with Applications, 36(2), pp.2843-2852.

Seo, K. (2016). Impacts of transportation investment on real property values: an analysis with spatial hedonic price models. Doctoral Dissertation. Arizona State University.

Siba, E. \& Sow, M. (2017). Financing African cities: what is the role of land value capture? The Bookings Institution. [Online]. Available at: https://www.brookings.edu/blog/africa-infocus/2017/12/14/financing-african-cities-what-is-the-role-of-landvalue-capture/ (Accessed: 30th November, 2019).

Smolka, M. (2019). Value capture and the property tax. Lincoln Institute of Land Policy. [Online]. Available at: https://www.lincolninst.edu/keyissues/value-capture-property-tax (Accessed: 12th January, 2020).

So, H., Tse, R. \& Ganesan, S. (1997). Estimating the influence of transport on house prices: evidence from Hong Kong, Journal of Property Valuation and Investment, 15(1), pp.40-47.

Soyeju, O. (2013). Legal framework for public private partnership in Nigeria. De Jure Law Journal, 46(3), pp.814-832.

Suzuki, H., Murakami, J., Hong, Y.H., \& Tamayose, B. (2015). Financing transit-oriented development with land values: adapting land value capture in developing countries. The World Bank. [Online]. Available at: $\quad$ https://openknowledge.worldbank.org/handle/10986/21286 (Accessed: 23rd August, 2020).

Tabachnick, B.G. \& Fidell, L.S. (2001) Using Multivariate Statistics (4th Edition). Boston: Allyn and Bacon.

Tse, R.Y.C. \& Love, P.E.D. (2000). Measuring residential property values in Hong Kong. Property Management 18(5), pp.366-374.

UKAid. (2015). Urban infrastructure in Sub-Saharan Africa- harnessing land values, housing and transport: Guideline for Cities in Sub-Saharan Africa on applying Land-Based. Financing for urban infrastructure finance Report 1.2. [Online]. Available at:

https://www.africancentreforcities.net/wpcontent/uploads/2015/09/DfID-Harnessing-Land-Values-Report-1.2City-guideline-20150728.pdf (Accessed: 12th April, 2019).

United Nations Human Settlements Programme- UN-Habitat. (2020). Where to start? A guide to land-based finance in local governance. United Nations Human Settlements Programme (UN-Habitat). [Online]. Available at: https://www.fig.net/resources/publications/un/2020 GLTNguide land-based finance.pdf (Accessed: 10th December 2020). 
Verougstraete, M. \& Zeng, H. (2014). Land value capture mechanism: the case of the Hong Kong mass transit railway. Public-private partnerships: case study. United nations economic and social commission for Asia and pacific. [Online]. Available at: https://www.unescap.org/sites/default/files/Case\%204\%20Land $\% 20$ Value $\% 20-\% 20$ Hong-Kong\%20MTR.pdf (Accessed: 23rd January, 2020).

Walters, L., Sietchiping, R. \& Haile, S. (2011). Land and property tax: a policy guide. United Nations Human Settlements Programme (UNHabitat). [Online]. Available at: https://unhabitat.org/land-andproperty-tax (Accessed: 16th June, 2014).

Walters, L.C. (2013). Land Value Capture in Policy and Practice. Journal of Property Tax Assessment \& Administration, 10(2), pp.5-21.

Wang J., Potoglou, D., Orford, S. \& Gong, Y. (2015). Bus stop, property price and land value tax: A multilevel hedonic analysis with quantile calibration. Journal of Land Use Policy, 42, pp381-391.

Weinberger, R.R. (2001). Commercial property values and proximity to light rail: a hedonic price application. Doctoral Dissertation. University of California, Berkeley. 